\title{
The Content of Toxic Metals in Agricultural Produce near a Coal Mine: Case Study KCB in Lazarevac, Serbia
}

\author{
Ana Koprivica ${ }^{1}$, Čedomir Beljić ${ }^{1}{ }^{(0)}$, Boris Vakanjac ${ }^{2}$, Vesna Ristić Vakanjac ${ }^{1, *}$ and \\ Marina Čokorilo Ilić ${ }^{1}$ \\ 1 Faculty of Mining and Geology, University of Belgrade, 11000 Belgrade, Serbia; \\ koprivicaana@gmail.com (A.K.); cedomir.beljic@rgf.bg.ac.rs (Č.B.); marina.cokorilo@rgf.bg.ac.rs (M.Č.I.) \\ 2 Singidunum University, Faculty for Applied Ecology "Futura", 11000 Belgrade, Serbia; \\ boris.vakanjac@futura.edu.rs \\ * Correspondence: vesna.ristic@rgf.bg.ac.rs; Tel.: +381-631679243
}

Received: 31 December 2017; Accepted: 16 March 2018; Published: 23 March 2018

\begin{abstract}
The monitoring and analysis of concentrations of toxic metals (lead and cadmium) in soils and crops indicate that farmland in Serbia is generally not polluted, and the quality of soils is naturally good. Such soils are therefore suitable for organic farming. All noted instances of contamination by toxic metals are of a local nature only, and the result of fertilizers and pesticides, municipal waste, exhaust gases, nearby production facilities, smelting plants, mines, tailings ponds, etc. Locations of this type need to be monitored regularly, and the status of the soil and crops assessed. The results presented in this paper place special emphasis on lead and cadmium. In this regard, the sampling of 67 plant foodstuffs that are being grown in Baroševac village, located in the immediate vicinity of the Kolubara coal mine, was carried out. Fruit samples represented $14.9 \%$ and vegetable samples $85.1 \%$ of the total sample. The heavy metal content (lead/cadmium) in seven samples was above the limits prescribed by the Regulations. Overall exposure of the adult population of Baroševac, calculated on the basis of all samples (67 in total), was $0.89 \mu \mathrm{g}$ lead per $\mathrm{kg}$ of body weight per week, representing only $3.5 \%$ provisional tolerable weekly intake (PTWI), and 0.46 cadmium per kg of body weight, which amounts to $6.7 \%$ PTWI. Both values point to the fact that the risk is low, even in the case of populations with high exposure to these toxic metals. This suggests that sustainable development may be possible in the near future.
\end{abstract}

Keywords: toxic metals; lead; cadmium; soil; crops; sustainable development

\section{Introduction}

Generally speaking, the problem of the quality of agricultural produce is becoming a problem on a global level. Urban and industrial centres, mines, large landfills, etc., have a direct impact on people living in their surroundings, and also an indirect impact, through food produced in the wider environment of these large sources of pollution, when consumed by people from the same locality or when it gets to the market. In this way, contaminated food, that has not been tested, can enter every household and have a significant impact on human health. In the wider scientific and professional public, a lot has been written about the consequences that a person who has spent a longer period of time exposed to contaminated food can face. Likewise, worldwide, in the wider environment of large sources of pollution, soil and produce analyses have been launched in order to attract public attention, as well as to inform the population living nearby about the hazards to which they are exposed.

For example, in the Tongling Mining area of China, the hazard index (HI) was more than 1 for the consumption of vegetables for both adults and children [1]. Zhou et al. [2] investigated heavy 
metal accumulation in 22 vegetable species in order to assess the human health risks of vegetable consumption. Taghipour and Maseferi Mosaferi [3] indicate the importance of monitoring the levels of heavy metals in vegetables in providing useful information for promoting food safety. A number of works [4-10] about heavy metals in the agricultural soils of the European Union and around the world and their implications for food safety have been written and published.

Can contemporary mining respond to the complex challenges of sustainable development, a concept increasingly seen as a solution for numerous problems created by the ongoing development of societies? This question is often raised by mining professionals and not only them.

Strictly speaking, it is difficult to harmonize the main postulates of the mineral industry with sustainable development.

Global warming, atmospheric pollution, and the degradation and pollution of soil and water are indisputable adverse effects of industrial activity and contemporary economies, in which mining has a not-so-small role.

Accelerating economic development worldwide and population growth are increasing the demand for mineral resources. The status and role of the mineral industry today are such that it is safe to conclude that on a global scale there are no adequate substitutes for its products.

The use of fossil fuels, particularly coal, is an especially delicate issue. It is well-known that the effects of burning coal are extremely harmful. Still, it is a fact that about $42 \%$ of the global energy supply is provided by burning coal. The percentage in Serbia is even larger.

The main supplier of coal in Serbia is the Kolubara Coal Basin in Lazarevac. This mining company produces about 30 million tons of lignite coal and some 70 million tons of overburden annually, of which 1.2 million tons of lignite coal is delivered to the consumer market. The Kolubara Coal Basin (KCB) operates within the Electric Power Industry of Serbia and (a) provides 70\% of its coal output; which (b) takes $70 \%$ of its coal output. KCB's share in Serbia's overall energy balance is $52 \%$, and coal is used to generate more than 20 billion $\mathrm{kW} \cdot \mathrm{h}$ [11].

Consequently, it is clear that the KCB is extremely important for Serbia's economy.

Given the social, economic, and manufacturing circumstances, it can easily be concluded that in the foreseeable future coal will remain the backbone of Serbia's power supply.

However, the production and burning of coal are a nightmare for all those involved in environmental protection, and not only them. To rephrase the earlier question: Is it possible to fully implement the concept of sustainable development in such circumstances?

The present paper does not aim to provide the final answer to this question. Instead, it presents the results of research on toxic metals in produce sampled from gardens in the immediate vicinity of open-pit coal mines, to draw attention to the need to examine the effect of mining on the environment. Only valid data and unbiased assessments will lead to an answer that is important to all those associated in any way with the mining industry.

\section{Toxic Metals in Soils and Food}

The origin of heavy, toxic metals in soils and food is either natural or anthropogenic. Anthropogenic drivers are associated with contamination during the course of farming, packaging, transporting, and processing produce. The toxic metals most often encountered are lead, cadmium, and arsenic.

The presence of these heavy metals in the human body affects bodily functions, causes various ailments, and may even lead to death [12].

According to Goldschmidt [13], lead, like cadmium, is a chalcophile element. Hydrothermal deposits of non-ferrous ores are its primary natural sources. Lead is generally associated with zinc (and copper). Galenite is the main lead mineral ore. There are also many other minerals, among which sulfosalts are the most interesting from the perspective of mineral ore exploration. In the atmosphere, lead is transformed into cerussite (lead carbonate) as well as some other minerals [14]. Lead has been in use since 7000 BC [15]. Ancient Rome used lead to fabricate 
water piping because of its resistance to corrosion. As a white pigment, it has been extensively used as the carbonate compound $2 \mathrm{PbCO}_{3} \cdot \mathrm{Pb}(\mathrm{OH})_{2}$, and also as a brownish-red paint to protect iron. Today, the largest amounts of lead are probably used in car batteries. Lead is also a common ingredient in gloss finishes in the ceramic industry.

In a natural environment, elevated concentrations of lead are often caused by mining operations, paints (especially if combusted), deposols originating from industrial facilities, ceramic waste, batteries, tetraethyl leaded gasoline, and piping joined with lead. It occurs in the air in the form of halides, and in water as colloidal particles of lead carbonate, lead oxide, lead hydroxide, etc. [16,17].

In rare cases, cadmium poisoning is lethal. Chronic exposure and intake of this metal over a protracted period of time is a health hazard [18]. It has been found to interfere with the cellular zinc balance. The absence of zinc or lack of iron in the body tends to enhance cadmium absorption [18,19]. Cadmium is carcinogenic [18-22].

Cadmium is toxic, and poisoning can occur even if present in traces. One of the widely reported cases is the itai-itai disease outbreak caused by cadmium poisoning in the Japanese Tojama Prefecture [23], which began in 1912 near mining operations (non-ferrous metals) and was recognized as such by the Japanese Ministry of Health in 1968 [24]. Cadmium had reached watercourses from the mines, tailing ponds, and ore processing plants. The symptoms of the disease are severe pain and spine/joint disorders.

The toxic metal most often found in food is mercury. It does not have a single positive effect on human metabolism, and its impact on the distribution and retention of other heavy metals makes it one of the most hazardous toxic metals [25]. Mercury exhibits its toxicity through exchange with iron and copper at active locations of enzymes used to produce energy. In addition, it can affect the nervous system, cardiovascular system, gastrointestinal tract, and kidneys (failure) [25,26], and can also accumulate in the thyroid gland, increasing the risk of autoimmune disorders [27].

Even though arsenic does not belong to the group of heavy metals, this metalloid (an element with both metal and non-metal properties) represents a risk to human health. People are generally exposed though the intake of food or water that contains arsenic. Inorganic arsenic binds hemoglobin in red blood cells and upon absorption quickly spreads to the liver, kidneys, heart, lungs, and to a lesser degree to the nervous system, gastrointestinal tract, and spleen [28]. The Public Health Institute of Serbia "Dr. Milan Jovanović Batut" has tested the health adequacy of crops and produce from Baroševac, a village which was chosen because of its proximity to the open-pit lignite coal mine KBC (Figure 1). Produce from gardens in the village was sampled in 2015 to determine the presence of toxic metals, primarily lead and cadmium.

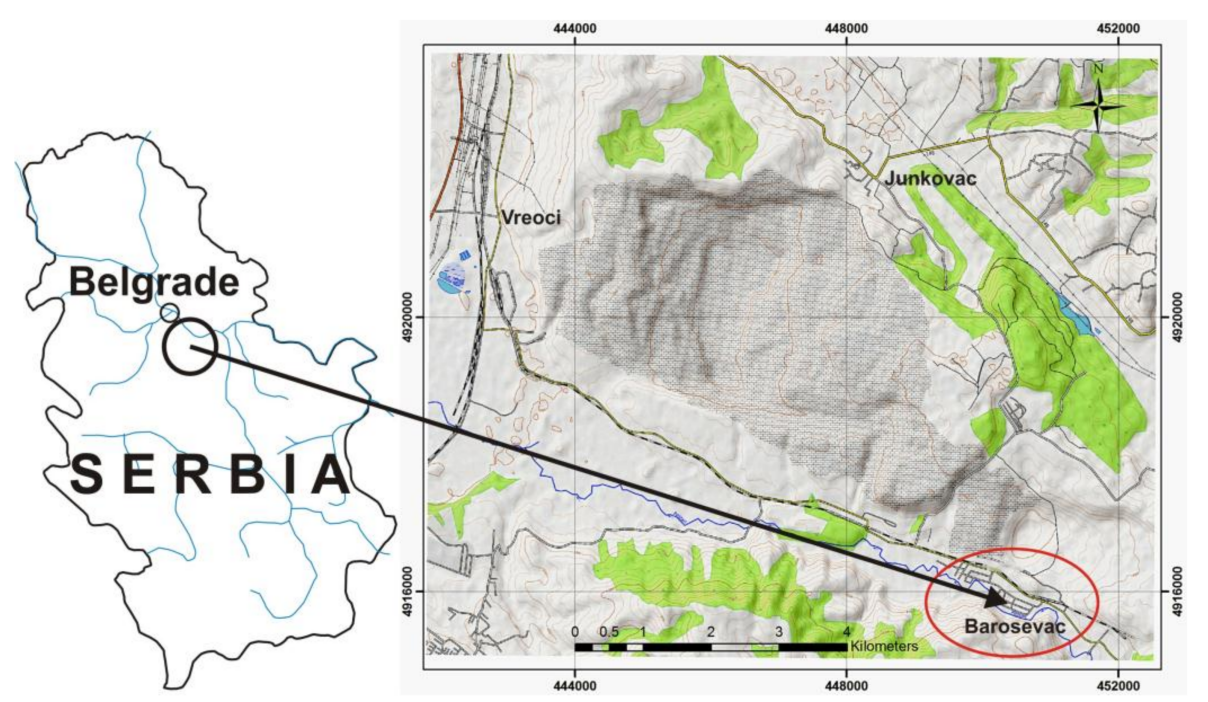

Figure 1. Geographic location of Baroševac. 


\section{Produce Sampling Method}

The produce from the Baroševac gardens was sampled according to the map shown in Figure 2. The sampling map was designed to cover the territory of the village evenly.

From the pre-determined eastern to western boundaries of Baroševac, the territory was divided into 14 quadrants, each $382.75 \mathrm{~m}$ long, plus an additional quadrant that was $513.9 \mathrm{~m}$ long [29]. From the pre-determined northern boundary (a regional road from Lazarevac to Aranđelovac and a further road to a weather station) to the southern boundary of the village (northern hills with a cemetery, and from there east and west to the edge of the village), the quadrants were divided into: (a) first-order quadrants adjacent to the regional road from Lazarevac to Aranđelovac and onward to the weather station, whose width was $100 \mathrm{~m}$; and (b) second-order quadrants, $200 \mathrm{~m}$ wide, continuing from the first-order quadrants.

The minimum $(100 \mathrm{~m})$ and maximum $(200 \mathrm{~m})$ quadrant widths were designated in alphabetical order from A to E, and numbered from 1 to 4 (Figure 2).

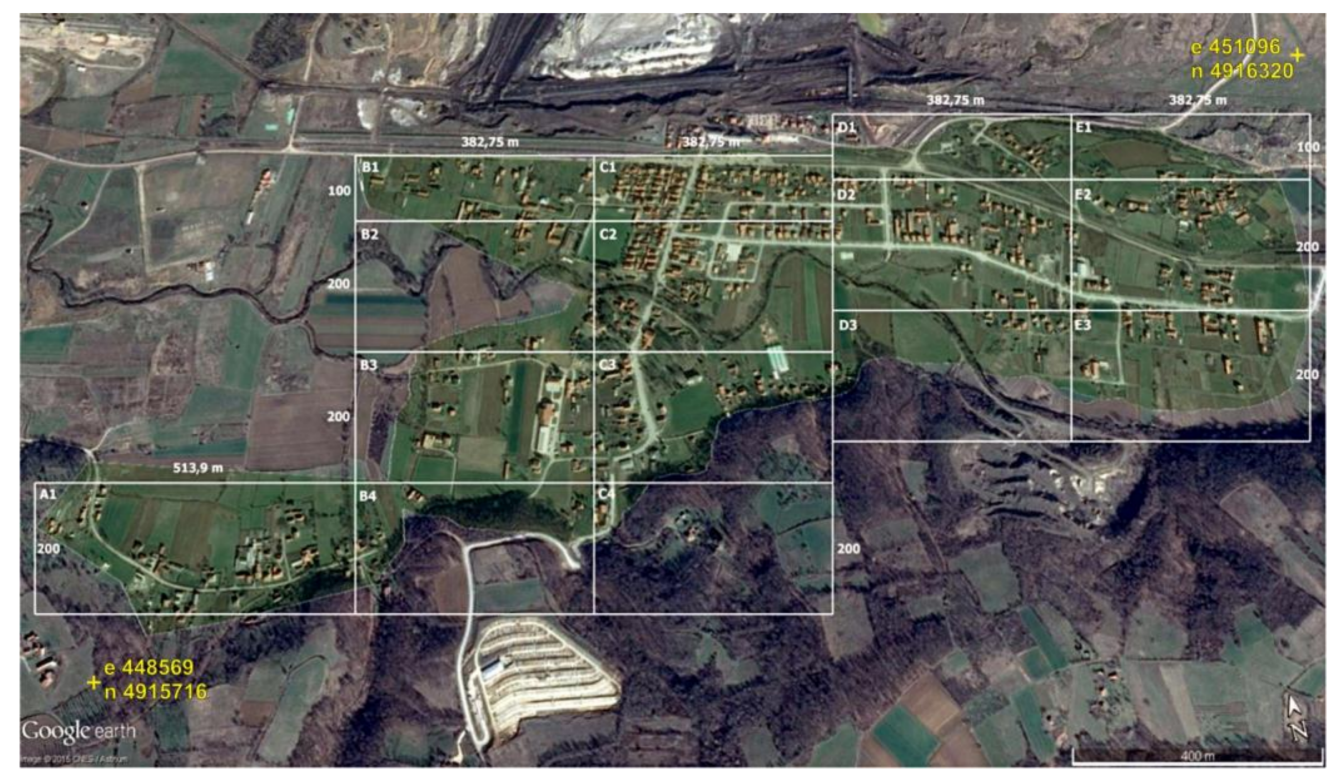

Figure 2. Produce sampling map of Baroševac

The number of samples of the produce to be analyzed was determined after creating the sampling map, taking into account the number of sampling points (households) and the types of produce expected to be grown in the Baroševac gardens. The selected number of samples was expected to provide a comprehensive picture of the health adequacy of produce in Baroševac.

Samples from the Baroševac gardens were collected in three campaigns, with 20-day intervals. Concentrations of toxic heavy metals (lead and cadmium) were determined. The analytical methods for lead and cadmium are shown in Table 1.

Table 1. Applied analytical methods for lead and cadmium [19].

\begin{tabular}{ccc}
\hline No. & Parameter & Method \\
\hline 1 & Lead concentration (atomic absorption, flame technique) & VDM-901\# \\
2 & Cadmium concentration (atomic absorption, flame technique) & VDM-901\# \\
\hline
\end{tabular}

National standards were used as a reference to assess the health adequacy of produce. 


\section{Exposure Assessment}

Exposure assessment (third phase of risk assessment) is defined as the evaluation of the intake of biological, chemical, or physical agents through food or other sources, if relevant to the agents under consideration. The intake of contaminants (lead and cadmium) through the produce sampled from gardens was evaluated for the adult population of Baroševac. Two approaches were followed to quantify the intake of contaminants:

- A deterministic model; and

- A semi-probabilistic model.

The deterministic model involved the use of fixed (average) amounts of consumed produce and the contaminant levels in the produce, which was the first step of risk assessment. The deterministic assessment of the intake of contaminants via produce from the Baroševac gardens was conducted using the following contaminant levels: average, 50th percentile, and 95th percentile.

The semi-probabilistic method was used to compare the measured concentration data (toxic metal content of produce, which are variable data) with fixed nutritional data. The data distribution and measurement uncertainties were taken into account by combining the variable data using the models. The result was a cumulative contaminant-intake distribution curve for the adult population of Baroševac. The assessed risk was expressed as a hazard index.

In the statistical analysis, the arithmetic mean, standard deviation, median, interquartile range, $95 \%$ confidence interval, frequency distribution, and percentages were used to describe and assess the data.

\section{Results}

The Baroševac gardens from which produce samples were collected to determine the concentrations of toxic metals are shown in Table 2.

Table 2. Distribution of produce samples from Baroševac family gardens.

\begin{tabular}{ccccccccccc}
\hline \multirow{2}{*}{ Sampled Family Garden } & \multicolumn{10}{c}{ Quadrant } \\
\cline { 2 - 9 } & B1 & B3 & C1 & C1/D2 & C2 & C3 & D1 & D2/D3 & E2/E3 & Total \\
\hline 1 & 0 & 0 & 0 & 0 & 0 & 0 & 0 & 0 & 4 & 4 \\
2 & 0 & 0 & 0 & 10 & 0 & 0 & 0 & 0 & 0 & 10 \\
3 & 5 & 0 & 0 & 0 & 0 & 0 & 0 & 0 & 0 & 5 \\
4 & 0 & 0 & 0 & 0 & 8 & 0 & 0 & 0 & 0 & 8 \\
5 & 0 & 1 & 0 & 0 & 0 & 0 & 0 & 0 & 0 & 1 \\
6 & 0 & 0 & 0 & 0 & 0 & 5 & 0 & 0 & 0 & 5 \\
7 & 0 & 0 & 0 & 0 & 0 & 13 & 0 & 0 & 0 & 13 \\
8 & 0 & 0 & 0 & 0 & 0 & 0 & 5 & 0 & 0 & 5 \\
9 & 0 & 0 & 7 & 0 & 0 & 0 & 0 & 0 & 0 & 7 \\
10 & 0 & 0 & 0 & 0 & 0 & 0 & 0 & 9 & 0 & 9 \\
Total & 5 & 1 & 7 & 10 & 8 & 18 & 5 & 9 & 4 & 67 \\
\hline
\end{tabular}

A total of 67 produce samples were collected to determine toxic metal concentrations: $85.1 \%$ were vegetable samples and $14.9 \%$ were fruit samples (Table 3 ). 
Table 3. Sampling dates and number of produce samples collected in village Baroševac during 2015.

\begin{tabular}{cccccc}
\hline \multirow{2}{*}{ Item } & Produce & \multicolumn{3}{c}{ Sampling Date } & \multirow{2}{*}{ Number of Samples } \\
\cline { 3 - 5 } & & 11 June & 9 July & 29 July & \\
\hline 1 & Aronia & 0 & 1 & 0 & 1 \\
2 & String beans & 0 & 3 & 0 & 3 \\
3 & Black currant & 1 & 0 & 0 & 1 \\
4 & Red currant & 2 & 0 & 0 & 2 \\
5 & Beet & 0 & 1 & 0 & 1 \\
6 & Apple & 0 & 1 & 1 & 2 \\
7 & Cucumber & 0 & 3 & 2 & 5 \\
8 & Potato & 0 & 7 & 0 & 7 \\
9 & Pear & 0 & 0 & 1 & 1 \\
10 & Onion & 0 & 1 & 6 & 7 \\
11 & Scallion & 9 & 0 & 0 & 9 \\
12 & New potato & 3 & 0 & 0 & 3 \\
13 & Pepper & 0 & 0 & 1 & 1 \\
14 & Tomato & 0 & 3 & 7 & 10 \\
15 & Scallion leaf & 0 & 0 & 2 & 2 \\
16 & Carrot & 0 & 6 & 0 & 6 \\
17 & Plum & 0 & 0 & 1 & 1 \\
18 & Zucchini & 0 & 1 & 0 & 1 \\
19 & Sour cherry & 2 & 0 & 0 & 2 \\
20 & Lettuce & 1 & 0 & 0 & 1 \\
21 & Green tomato & 0 & 1 & 0 & 1 \\
\hline & Total & 28 & 21 & 67 \\
\hline
\end{tabular}

\section{Lead and Cadmium Concentrations in Produce}

Heavy metal (lead/cadmium) concentrations above stipulated threshold values were detected in 7 of 67 , or $10.4 \%$, of the tested samples (Figure 3). Of all the samples tested for lead, seven had concentrations higher than the prescribed threshold values (Figures 3 and 4).

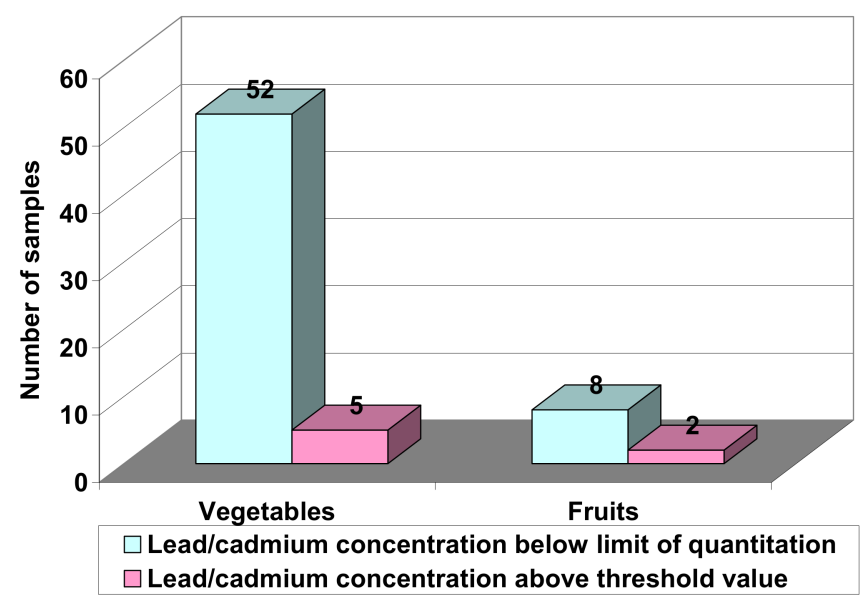

Figure 3. Lead and cadmium concentrations in produce samples from Baroševac. 


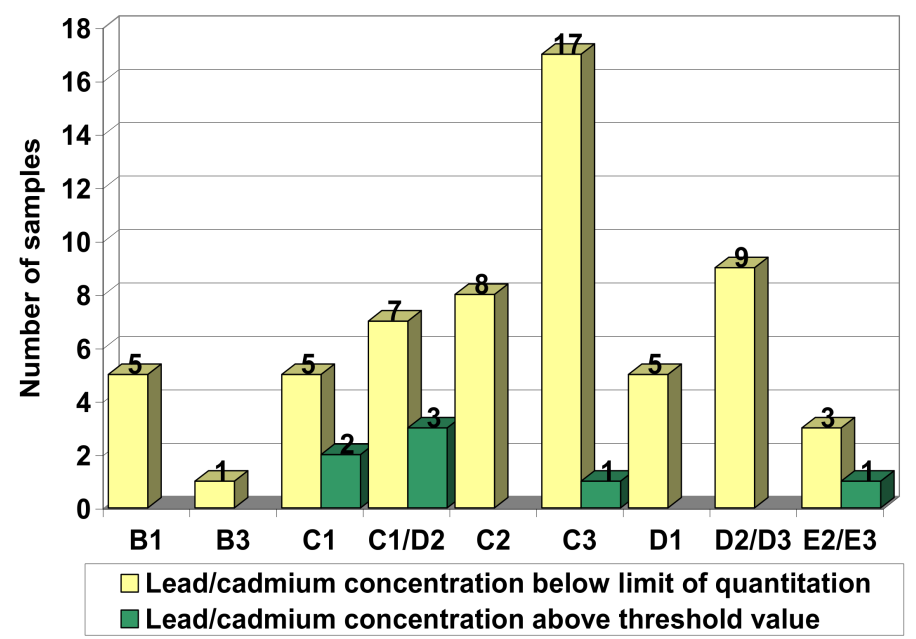

Figure 4. Distribution of produce samples based on lead concentrations and respective quadrants in Baroševac.

The types of produce from Baroševac whose lead concentrations were above threshold values are shown in Table 4. The highest concentration of lead was determined in the case of new potato (vegetable) and black currant (fruit).

Table 4. Types of produce and number of samples in which lead concentrations exceeded threshold values in village Baroševac during 2015.

\begin{tabular}{|c|c|c|c|c|c|}
\hline \multirow{3}{*}{ Type of Produce } & \multicolumn{4}{|c|}{ Quadrant } & \multirow{3}{*}{ Number of Samples } \\
\hline & $\mathrm{C1}$ & C1/D2 & C3 & E2/E3 & \\
\hline & \multicolumn{4}{|c|}{ Number of Tested Samples (Lead Concentration in mg/kg) } & \\
\hline Black currant & & & $1(0.37)$ & & 1 \\
\hline Red currant & $1(1.27)$ & & & & 1 \\
\hline Scallion & & $1(0.32)$ & & & 1 \\
\hline New potato & $1(1.08)$ & & & & 1 \\
\hline Tomato & & & & $1(0.62)$ & 1 \\
\hline Zucchini & & $1(0.65)$ & & & 1 \\
\hline Green tomato & & $1(0.25)$ & & & 1 \\
\hline Total & 2 & 3 & 1 & 1 & 7 \\
\hline
\end{tabular}

Of all the produce samples tested for cadmium, the concentration in only one sample exceeded the threshold value (Figure 5). 


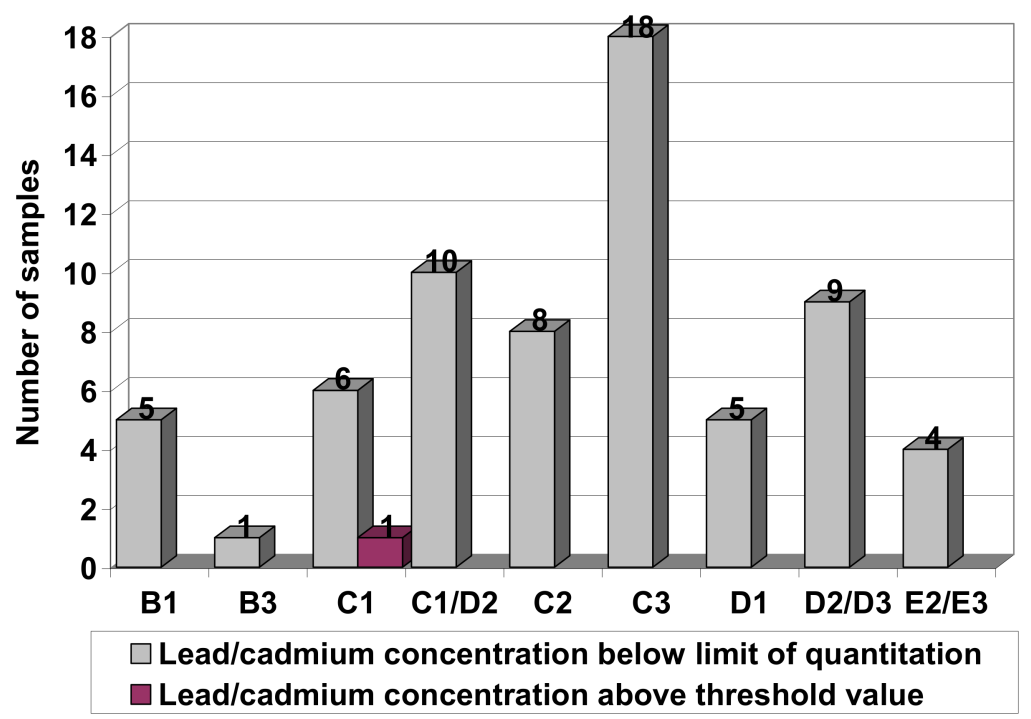

Figure 5. Distribution of the number of produce samples based on cadmium concentration and respective quadrants in Baroševac.

The type of produce from Baroševac in which cadmium concentration exceeded the threshold value is shown in Table 5.

Table 5. Type of produce and number of samples in which cadmium concentration exceeded threshold value village Baroševac during 2015.

\begin{tabular}{cccccc}
\hline \multirow{2}{*}{ Type of Produce } & \multicolumn{5}{c}{ Quadrant } \\
\cline { 2 - 4 } & C1 & C1/D2 & C3 & E2/E3 & \\
\cline { 2 - 4 } & \multicolumn{2}{c}{ Number of Tested Samples (Cadmium Concentration in $\mathbf{m g} / \mathbf{k g})$} & \\
\hline Red currant & $1(0.73)$ & - & - & - & 1 \\
Total & 1 & - & - & - & 1 \\
\hline
\end{tabular}

\section{Deterministic and Semi-Probabilistic Risk Assessment}

\subsection{Exposure of Baroševac's Adult Population to Lead through Produce Grown in Baroševac Gardens}

The deterministic method-using fixed (average) values of parameters (amount of produce consumed, lead concentration in produce sampled from Baroševac gardens, average body weight of $77.05 \mathrm{~kg}$ ) - were applied to determine the total weekly intake of lead by the adult population of Baroševac in three different scenarios (Table 6).

Table 6. Baroševac adult population's weekly intake of lead and hazard index (deterministic model).

\begin{tabular}{cccc}
\hline Estimated Lead Intake ( $\boldsymbol{\mu} / \mathbf{k g}$ of Body Weight) & Scenario A & Scenario B & Scenario C \\
\hline Total daily * & 0.540240872 & 0.124585075 & 2.290171 \\
Total weekly * & 3.781686107 & 0.872095522 & 16.031199 \\
Hazard index & 0.151267444 & 0.034883821 & 0.641248 \\
\hline
\end{tabular}

A: average lead concentration; B: 50th percentile; C: 95th percentile; ${ }^{*}$ through produce sampled from Baroševac gardens.

Scenario B exhibited the lowest and Scenario $C$ the highest lead intake. The hazard index was derived by comparing the estimated weekly intake with the provisional tolerable weekly intake (PTWI) of $25 \mu \mathrm{g} / \mathrm{kg}$ of body weight, which is recommended by the World Health Organization and adopted 
by the former Scientific Committee on Food of the European Commission, now the European Food Safety Authority. The hazard index in all three scenarios was less than 1.

The average, median (50th percentile), and maximum (95th percentile) weekly lead intakes were also estimated using a Monte Carlo simulated cumulative curve and the hazard index was calculated accordingly (Table 7).

Table 7. Baroševac adult population's lead intake and index hazard (semi-probabilistic method).

\begin{tabular}{cccc}
\hline Estimated Lead Intake ( $\boldsymbol{\mu} / \mathbf{k g}$ of Body Weight) & Scenario A & Scenario B & Scenario C \\
\hline Total daily * & 0.000126684 & 0.272577851 & 2.027715 \\
Total weekly * & 0.886785607 & 1.908044954 & 14.19401 \\
Hazard index & 0.035471424 & 0.076321798 & 0.56776 \\
\hline
\end{tabular}

A: average lead concentration; B: 50th percentile; C: 95th percentile; ${ }^{*}$ through produce sampled from Baroševac gardens.

The hazard indices in all scenarios, including the average exposure to lead, the 50th percentile, and the 95th (maximum) percentile, were less than 1.

\subsection{Exposure of Baroševac's Adult Population to Cadmium via Produce Sampled from Baroševac Gardens}

The deterministic method-using fixed (average) values of parameters (amount of consumed produce, cadmium concentration in produce sampled from Baroševac gardens, average body weight of $77.05 \mathrm{~kg}$ ) — was applied to calculate the total weekly intake of cadmium by the adult population of Baroševac in three different scenarios (Table 8).

Table 8. Baroševac adult population's weekly cadmium intake and hazard index (deterministic method).

\begin{tabular}{cccc}
\hline Estimated Cadmium Intake ( $\boldsymbol{\mu} / \mathbf{k g}$ of Body Weight) & Scenario A & Scenario B & Scenario C \\
\hline Total daily * & 0.000103545 & 0.000033566 & 0.000424767 \\
Total weekly & 0.000724816 & 0.000234961 & 0.002973367 \\
Hazard index & 0.000103545 & 0.000033566 & 0.000424767 \\
\hline
\end{tabular}

A: average cadmium concentration; B: 50th percentile; C: 95 th percentile; ${ }^{*}$ through produce sampled from Baroševac gardens.

Scenario B exhibited the lowest and Scenario $C$ the highest cadmium intake. The hazard index was derived by comparing the estimated weekly intake with a PTWI of $7 \mu \mathrm{g} / \mathrm{kg}$ of body weight, which is approved by the former Scientific Committee on Food of the European Commission, now the European Food Safety Authority. The hazard index in all three scenarios was less than 1.

The average, median (50th percentile), and maximum (95th percentile) weekly cadmium intakes were also estimated using a Monte Carlo simulated cumulative curve and the hazard index was calculated accordingly (Table 9).

Table 9. Baroševac adult population's weekly cadmium intake and hazard index (semi-probabilistic method).

\begin{tabular}{cccc}
\hline Estimated Cadmium Intake ( $\boldsymbol{\mu} / \mathbf{k g}$ of Body Weight) & Scenario A & Scenario B & Scenario C \\
\hline Total daily * & 0.067142194 & 0.092236924 & 0.2942056 \\
Total weekly * & 0.469995356 & 0.645658465 & 2.0594392 \\
Hazard index & 0.067142194 & 0.092236924 & 0.2942056
\end{tabular}

A: average lead concentration; B: 50th percentile; C: 95th percentile; ${ }^{*}$ through produce sampled from Baroševac gardens.

The hazard indices in all scenarios, including the average exposure to cadmium, the 50th percentile, and the 95th (maximum) percentile, were less than 1. 


\section{Discussion and Conclusions}

The increase of the presence of heavy metals in soils and food is matched by the increase of studies of the consequences of their impact on human health [30-39].

According to national standards concerning residues of plant protection agents in produce and animal feed and the prescribed threshold levels [40], lead concentrations in excess of threshold values were detected in seven produce samples.

Among the family gardens, from which produce samples that exhibited lead concentrations above threshold values were collected,

- Three were located near roads (two in cartographic quadrant $\mathrm{C} 1$ and one on the boundary between quadrants E2 and E3); it is believed that the reason for the elevated concentrations in this case was the proximity of roads used by passenger vehicles and mobile mining machinery.

- One was located in quadrant C3, although in another quadrant, about $70 \mathrm{~m}$ away, the produce samples were healthy. The two quadrants were not adjacent to each other. Because this was an isolated case, the elevated concentration might have been caused by fertilizers.

An elevated concentration of cadmium was detected in one of the 67 tested samples (black currant, quadrant C3). This finding suggests either an isolated case of contamination (say by fertilizers) or a plant-specific increased cadmium uptake from the soil.

The exposure of adults to lead and cadmium in Baroševac via the produce grown in family gardens was assessed on the basis of 67 samples. The average exposure to lead was found to be $0.89 \mu \mathrm{g}$ per kilogram of body weight per week, or $3.5 \%$ of PTWI (provisional tolerable weekly intake), which amounts to a low level of risk. Even in the case of high exposure, the risk is low: $56.8 \%$ of PTWI. The average exposure of adults in Baroševac to cadmium via produce grown in private gardens was found to be $0.46 \mu \mathrm{g}$ per kilogram of body weight, which implies a low level of risk. Even in the case of high exposure to cadmium, the risk is low: $29.4 \%$ of PTWI.

For the purpose of a detailed exposure assessment, further monitoring of the content of heavy metals in fruit and vegetables, grown in the gardens of Baroševac, is necessary. The reason is the fact that the open-pit mine (KCB) is still active and it is expanding, which can influence the further increase of the concentrations of the considered toxic elements in the fruit and vegetables grown in Baroševac. One fifth of households (21.4\%) in Baroševac meets their needs with home-produced fruit and vegetables. The rest of the vegetables are sent to the green markets in Lazarevac, Stepojevac, and a smaller part in Belgrade, whereby random customers can be endangered to a lesser extent. It can be said that the aforementioned part of the population of Baroševac, which exclusively consumes its own produce, could be at potential risk of continually ingesting toxic metals over a longer period of time.

The growing of produce near active strip mines should certainly be avoided. However, given the situation in the case study, the households whose sampled produce exhibited lead and cadmium concentrations in excess of legal threshold values should receive advice about the produce they grow and how they can check the health adequacy of the crops.

Author Contributions: Ana Koprivica and Čedomir Beljić carried out field work and sampling procedures, Ana Koprivica provided assaying, Boris Vakanjac establish data base, Vesna Ristić Vakanjac and Marina Čokorilo Ilić worked on statistical and data processing, all authors were involved in data compilation.

Conflicts of Interest: The authors declare no conflict of interest.

\section{References}

1. Ding, Z.; Li, Y.; Sun, Q. Trace elements in soils and selected agricultural plants in the tongling mining area of China. Int. J. Environ. Res. Public Health 2018, 25. [CrossRef] [PubMed]

2. Zhou, H.; Yang, W.T.; Zhou, X.; Liu, L.; Gu, J.F.; Wang, W.L.; Zou, J.L.; Tian, T.; Peng, P.Q.; Liao, B.H. Accumulation of heavy metals in vegetable species planted in contaminated soils and the health risk assessment. Int. J. Environ. Res. Public Health 2016, 13, 289. [CrossRef] [PubMed] 
3. Taghipour, H.; Mosaferi, M. Heavy metals in the vegetables collected from production sites. Health Promot. Perspect. 2013, 3, 185-193. [CrossRef] [PubMed]

4. Tóth, G.; Hermann, T.; Da Silva, M.R.; Montanarella, L. Heavy metals in agricultural soils of the European Union with implications for food safety. Environ. Int. 2016, 88, 299-309. [CrossRef] [PubMed]

5. Tóth, G.; Hermann, T.; Syatmári, G.; Pásztor, L. Maps of heavy metals in the soils of the European Union and proposed priority areas for detailed assessment. Sci. Total Environ. 2016, 565, 1054-1062. [CrossRef] [PubMed]

6. Bystricka, J.; Kavalcova, P.; Musilova, J.; Karovicova, J.; Kuchtova, V. The effect of variety on heavy metals intake by onion grown in contaminated soil. In Proceedings of the 14th International Conference on Environmental Science and Technology Greece, Rhodes, Greece, 3-5 September 2015.

7. Becquer, T.; Quantin, C.; Boudot, J.P. Toxic levels of metals in Ferralsols under natural vegetation and crops in New Caledonia. Eropean J. Soil Sci. 2010, 61, 994-1004. [CrossRef]

8. Khanna, P. Assessment of heavy metal contamination in different vegetables grown in and around urban areas. Res. J. Environ. Toxicol. 2011, 5, 162-179. [CrossRef]

9. Gergen, J.; Harmanescu, M. Application of principal component analysis in the pollution assessment with heavy metals of vegetable food chain in the old mining areas. Chem. Cent. J. 2012, 6, 156. [CrossRef] [PubMed]

10. McBride, M.B.; Shayler, H.A.; Spliethoff, H.M.; Mitchell, G.I.; Marquez-Bravo, L.G.; Ferenz, G.S.; Russell-Anelli, J.M.; Casey, L.; Bachman, S. Concentrations of lead, cadmium and barium in urban garden-grown vegetables: The impact of soil variables. Environ. Pollut. 2014, 194, 254-261. [CrossRef] [PubMed]

11. Rudarski Basen Kolubara. Available online: http://www.poslovnivodic.com/rudarski-basen-kolubara.html (accessed on 9 December 2017).

12. Kirberger, M.; Wong, H.C.; Jiang, J.; Yang, J.J. Metal toxicity and opportunistic binding of $\mathrm{Pb}^{2+}$ in proteins. J. Inorg. Biochem. 2013, 125, 40-49. [CrossRef] [PubMed]

13. Goldschmidt, V.M. The principles of distribution of chemical elements in minerals and rocks. The seventh Hugo Müller Lecture, delivered before the Chemical Society. J. Chem. Soc. 1937, 0, 655-673. [CrossRef]

14. Tomanec, R.; Vakanjac, B. Rudne Parageneze sa Metodama Ispitivanja i Atlasom Karakterističnih Primera, Monografija; Aleksić, J., Ed.; Singidunum University: Belgrade, Serbia, 2015; ISBN 978-86-86859-45-7.

15. Rich, V. The International Lead Trade; Woodhead Publishing: Shaston, UK, 2014; p. 4, ISBN 978-0-85709-994-5.

16. ATSDR. ToxGuide for Lead. 2008; pp. 1-2. Available online: http://www.atsdr.cdc.gov/toxguides/toxguide13.pdf (accessed on 11 December 2017).

17. ATSDR. Toxicological Profile for Lead. 2007; pp. 1-582. Available online: http://www.atsdr.cdc.gov/ toxprofiles/tp13.pdf (accessed on 11 December 2017).

18. Thévenod, F.; Lee, W.K. Toxicology of cadmium and its damage to mammalian organs. Met. Ions Life Sci. 2013, 11, 415-490. [PubMed]

19. Sigel, A.; Sigel, H.; Sigel, R. Cadmium: From Toxicity to Essentiality; Springer: Dordrecht, The Netherlands, 2013.

20. ATSDR. Toxicological Profile for Cadmium. 2012; pp. 1-487. Available online: http://www.atsdr.cdc.gov/ toxprofiles/tp5.pdf (accessed on 12 December 2017).

21. ATSDR. ToxGuide for Cadmium. 2012; pp. 1-2. Available online: www.atsdr.cdc.gov/toxguides/toxguide-5. pdf (accessed on 12 December 2017).

22. Sinicropi, M.S.; Amantea, D.; Caruso, A.; Saturnino, C. Chemical and biological properties of toxic metals and use of chelating agents for the pharmacological treatment of metal poisoning. Arch. Toxicol. 2010, 84, 501-520. [CrossRef] [PubMed]

23. Yoshida, F.; Hata, A.; Tonegawa, H. Itai-Itai disease and the countermeasures against cadmium pollution by the Kamioka mine. Environ. Econ. Policy Stud. 1999, 2, 215-229. [CrossRef]

24. Gresser, J.; Fujikuram, K.; Morishuma, A. Environmental Law in Japan; MIT Press: Cambridge, MA, USA, 1981; p. 525.

25. Houston, M.C. Role of mercury toxicity in hypertension, cardiovascular disease, and stroke. J. Clin. Hypertens. 2011, 13, 621-627. [CrossRef] [PubMed]

26. ATSDR. Mercury ToxFAQ. 2000; pp. 1-2. Available online: http://www.atsdr.cdc.gov/toxfaqs/tfacts46_ metallic_mercury.pdf (accessed on 12 December 2017). 
27. Gallagher, C.M.C.; Meliker, J.R.J. Mercury and thyroid autoantibodies in U.S. women, NHANES 2007-2008. Environ. Int. 2012, 40, 39-43. [CrossRef] [PubMed]

28. Ibrahim, D.; Froberg, B.; Wolf, A.; Rusyniak, D.E. Heavy Metal Poisoning: Clinical Presentations and Pathophysiology. Clin. Lab. Med. 2006, 26, 67-97. [CrossRef] [PubMed]

29. Autora, G. Analiza Rezultata Ispitivanja Zdravstvene Ispravnosti Namirnica Biljnog Porekla iz Bašti Naselja Baroševac-Sadržaj Teških i Toksičnih Metala (Pb, Cd, $\mathrm{Hg}$, As); Institut za javno zdravlje Srbije, 'Dr. Milan Jovanović Batut': Beograd, Serbia, 2016.

30. Hatem, M.; Parvez, I.H.; Eid, I.B. Estimated dietary intakes of toxic elements from four staple foods in Najran city, Saudi Arabia. Int. J. Environ. Res. Public Health 2017, 14, 1575. [CrossRef]

31. Saint-Laurent, D.; Hähni, M.; St-Laurent, J.; Baril, B. Comparative Assessment of Soil Contamination by Lead and Heavy Metals in Riparian and Agricultural Areas (Southern Québec, Canada). Int. J. Environ. Res. Public Health 2010, 7, 3100-3114. [CrossRef] [PubMed]

32. Obiri, S.; Yeboah, P.O.; Osae, S.; Adu-kumi, S.; Cobbina, S.J.; Armah, F.A.; Ason, B.; Antwi, E.; Quansah, R. Human Health Risk Assessment of Artisanal Miners Exposed to Toxic Chemicals in Water and Sediments in the PresteaHuni Valley District of Ghana. Int. J. Environ. Res. Public Health 2016, 13, 139. [CrossRef] [PubMed]

33. Shabbaj, I.I.; Alghamdi, M.A.; Shamy, M.; Hassan, S.K.; Alsharif, M.M.; Khoder, M.I. Risk assessment and implication of human exposure to road dust heavy metals in Jeddah, Saudi Arabia. Int. J. Environ. Res. Public Health 2018, 15, 36. [CrossRef] [PubMed]

34. Liu, K.; Shang, Q.; Wan, C.; Song, P.; Ma, C.; Cao, L. Characteristics and sources of heavy metals in PM2.5 during a typical haze episode in rural and urban areas in Taiyuan, China. Atmosphere 2018, 9, 2. [CrossRef]

35. Santos-Francés, F.; Martínez-Graña, A.; Ávila Zarza, C.; García Sánchez, A.; Alonso Rojo, P. Spatial distribution of heavy metals and the environmental quality of soil in the Northern Plateau of Spain by geostatistical methods. Int. J. Environ. Res. Public Health 2017, 14, 568. [CrossRef] [PubMed]

36. Bortey-Sam, N.; Nakayama, S.M.M.; Akoto, O.; Ikenaka, Y.; Baidoo, E.; Mizukawa, H.; Ishizuka, M. Ecological risk of heavy metals and a metalloid in agricultural soils in Tarkwa, Ghana. Int. J. Environ. Res. Public Health 2015, 12, 11448-11465. [CrossRef] [PubMed]

37. Song, D.; Zhuang, D.; Jiang, D.; Fu, J.; Wang, Q. Integrated health risk assessment of heavy metals in Suxian County, South China. Int. J. Environ. Res. Public Health 2015, 12, 7100-7117. [CrossRef] [PubMed]

38. Lim, M.; Han, G.C.; Ahn, J.W.; You, K.S.; Kim, H.S. Leachability of Arsenic and heavy metals from mine tailings of abandoned metal mines. Int. J. Environ. Res. Public Health 2009, 6, 2865-2879. [CrossRef] [PubMed]

39. Jia, L.; Wang, W.; Li, Y.; Yang, L. Heavy metals in soil and crops of an intensively farmed area: A case study in Yucheng City, Shandong Province, China. Int. J. Environ. Res. Public Health 2010, 7, 395-412. [CrossRef] [PubMed]

40. Pravilnik o Maksimalno Dozvoljenim Količinama Ostataka Sredstava za Zaštitu Bilja u Hrani i Hrani za Životinje io Hrani i Hrani za Životinje za Koju se Utvrđuju Maksimalno Dovoljene Količine Ostataka Sredstava za Zaštitu Bilja; Službeni glasnik Republike Srbije: Belgrade, Serbia, 2014.

(C) 2018 by the authors. Licensee MDPI, Basel, Switzerland. This article is an open access article distributed under the terms and conditions of the Creative Commons Attribution (CC BY) license (http://creativecommons.org/licenses/by/4.0/). 